Research Article

\title{
BIOACCUMULATION OF HEAVY METALS: LEAD AND CADMIUM IN DIFFERENT ORGANS OF ROHU (LABEO ROHITA) OF RIVER INDUS AT DISTRICT SWABI, KHYBER PAKHTOONKHWA, PAKISTAN
}

\author{
Irfan Ali*, Ahsan Khan and Mohsin Khan \\ Department of Zoology University of Swabi, KPK, Pakistan
}

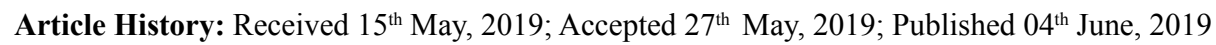

\begin{abstract}
The present study was conducted on different sites of River Indus to find out the concentration and accumulation of heavy metals; Lead and Cadmium in gills, swim bladder and muscles of Rohu. The fish were collected from three different sites Topi, Hund and Kund of River Indus at Swabi, KPK Pakistan in the month of February, March, and April 2016 respectively. Results led to the conclusion that the accumulation of heavy metals in the month of February in gills were in order $\mathrm{Pb}(0.05$ ppm $)>\mathrm{Cd}(0.04 \mathrm{ppm})$ Swim Bladder $\mathrm{Pb}(0.02 \mathrm{ppm})>\mathrm{Cd}(\mathrm{N} . \mathrm{D})$ and Muscle $\mathrm{Pb}(0.03 \mathrm{ppm})>\mathrm{Cd}(\mathrm{N} . \mathrm{D})$ respectively. The overall accumulation of heavy metals in Rohu in month of March in Gills were in order $\mathrm{Pb}(0.04 \mathrm{ppm})>\mathrm{Cd}(0.01 \mathrm{ppm}) \mathrm{Swim}$ Bladder $\mathrm{Pb}(0.02 \mathrm{ppm})<\mathrm{Cd}(0.03 \mathrm{ppm})$ and Muscle $\mathrm{Pb}(0.02 \mathrm{ppm})>\mathrm{Cd}(0.01 \mathrm{ppm})$ respectively. The overall accumulation of heavy metals in Rohu in month of April was in Swim Bladder $\mathrm{Pb}(0.01 \mathrm{ppm})<\mathrm{Cd}(0.02 \mathrm{ppm})$. Lead concentration was in gills and muscle organs $(0.03 \mathrm{ppm})$ and was no cadmium was observed in Gills and muscle organs of Labeo rohita.
\end{abstract}

Keywords: River Indus, Fish, Rohu, Heavy metals, Organs, Swabi, Pakistan

\section{INTRODUCTION}

Pollution of the Indus River by heavy metals is a major problem in Pakistan. Different human activities on land, water and air contribute to the pollution of River Indus in Pakistan. The Indus River with 970,000 $\mathrm{km}^{2}$ drainage basin area is one of the world's major discharge and sediment load River. It is contaminated with industrial and domestic sewage. Rapid industrialization (cement, cotton ginning and pressing, fertilizers and flour mills) has also increased the level of contamination by the release of unrefined waste products into the River Indus (Jabeen et al., 2010). Toxic heavy metals which are dense metals noted for potential toxicity in the environment (Srevastava et al., 2010). The heavy metals are entering to the environment by means of natural and anthropogenic. These sources are natural weathering of the earth's crust's, soil erosion, mining, urban run- off, pesticides, industrial sewage, sewage effluents, pest or disease control agents applied to plants, air pollution fallout, and a number of others (Ming Ho 2005). Heavy metals include cadmium, lead, mercury, these are appear in the organization's list of top 10 chemical of major public concern also it also include other example chromium, manganese, cobalt, nickel, copper, selenium, silver, antimony and thallium (Harvey et al., 2015). Essential and non-essential metals can disrupt metabolic and physiological activities of organisms at higher concentration. The concentration of essential metals exceed from permissible level it become a toxic (Wright et al., 2002). Lead $(\mathrm{Pb})$, cadmium $(\mathrm{Cd})$, mercury $(\mathrm{Hg})$ and arsenic (As) *Corresponding author e-mail: Irfanalbdrian@gmail.com are widely dispersed in the environment but they have no beneficial effects and homoeostasis mechanism in human body (Draghici et al., 2010). Various metals get absorbed and transported to different organs through blood either for storage or excretion. Level of trace metals in different organs is used as an index of metal pollution in an ecosystem, for highlighting health of an organism important tool is to be considered. Behavioral and morphological abnormalities such as alternation in sensory reception, reduced responses to normal olfactory function (feeding, mating, selection, or homing), loss of reproductive efficiency, reduction in swimming performance, gill purge, ventilation, coughs, loss of equilibrium that lapsed into paralysis, and irregular metamorphosis appeared as symptoms of toxic exposure to trace metals (Vieira et al., 2011). Toxicologically relevant element lead was added by man to the environment in extreme amount (Sesli et al., 2008). Lead enters though run off in to water system industrial and sewage wastes streams. If the concentration of lead in water increases, this can damage some aquatic life as well as blood nervous change in animal and fish and others (Atchison et al., 1987). Lead also damage the central nervous system brain, kidney, liver, and reproductive system in human as well as fish (Oehlenschläger et al., 2002). In the environment cadmium naturally present in soil, air, sediments and unpolluted seawater. Cadmium is emitted to air by mines, industries using cadmium compounds for alloy, batteries and metal smelter, pigments and in plastics (Kalay et al., 1999). Tobacco smoke is one of the largest single sources of cadmium exposure in human. Because of the 
absorption of cadmium from lungs much greater than from the gastrointestinal tract, smoking contributes significantly to the total body burden (Ademoroti et al., 1996). Cadmium can damage poor reproductive capacity and kidney function in fish (Harrison et al., 2001). Cadmium also damage several organs in human body liver, lungs, bones and central nervous system (Figueroa et al., 2008). From Tibetan plateau western China Indus river arising travels northwest through the Himalayan valleys and after crossing into the Kashmir region and traversing Pakistan, flows out into the Arabian Sea (Mansour et al., 2002). In Pakistan only river Indus is the single major water resource, depending heavily seasonal rain fall and glacial melt for its average fall, the Indus basin system is the backbone of agrarian economy of Pakistan with drainage area is $56 \%$ (González et al., 2008). Labeo rohita has nutritive and commercial as well as economic value; therefore, the present study was conducted to represent some scientific information about the bioaccumulation of lead and cadmium in different organ (such as gills, swim bladder and muscle) of Labeo rohita.

\section{MATERIALS AND METHODS}

During the collection of fish and the research was carried out in the laboratory, following materials were used.

Hand nets, hooks, nets, and fishing rods. Scissors and surgical blades were used for dissection purpose and for sample digestion process 3:1 solution of $\mathrm{HCLO}_{4}$ (Perchloric acid) and $\mathrm{H}_{2} \mathrm{SO}_{4}$ (Sulphuric acid) $15 \mathrm{ml}$ were used for 1 gram sample. Inside the laboratory others materials such as electronic weighting balance, micro oven, hot plates, masks, beakers, conical flasks, counting needles, gloves, forceps, petri dish, and fuming hood machine were used. Atomic absorption spectroscopy machine were used for metals detection in sample.

\section{Sample collection and digestion}

\section{Sample collection}

Samples were collected in three different months from three different sites. In February, March, and April fish were collected from Topi, Hund, and Kund respectively. The fish were collected by using meshed cast nets, by fishing rods, by hooks, and also with help of scope nets.

\section{Sample digestion}

After collection labeling, identification and dissection of the fishes the sample were carried to PCSIR lab Peshawar. For removal of ice sample were kept for ten minutes in open place. To remove impurities beaker were washed with distilled water. For drying purpose beakers were then kept in micro oven for 5 minutes. For the removal of moisture beaker were kept in desiccator. Then the $40 \mathrm{ml}$ beakers were put on weighting balance. After that ice were melts from the samples. A small piece was cut out from gills, swim bladder and muscles tissue respectively, and put into beakers. On the weighting balance sample were weighted and noted. After that 3:1 solution of $\mathrm{HCLO}_{4}$ (per chloric acid) and $\mathrm{H}_{2} \mathrm{SO}_{4}$ (Sulphuric acid) into a beaker the beaker was shake gently to mix the reagents. After that beaker was put on hot plate and heat it at $100^{\circ} \mathrm{C}$. beakers were heated until the white fume of $\mathrm{H}_{2} \mathrm{SO}_{4}$ (Sulphuric acid) appear leaving a clear solution having in organic matters appear while organic matter are digest and evaporates from solution. Distilled water was used to prevent the solution from drying. After that $50 \mathrm{ml}$ graduated funnels were taken and cleared with distal water to remove impurities from it. For drying purpose it were kept in oven. For removal of moisture the graduated funnels were kept in desiccators. After that it solution was filter with the help of filter paper from the beaker into the funnel. Then finally the sample was run with atomic absorption spectroscopy machine for the detection of heavy metals in it. After the digestion and filtration of sample it were run through atomic absorption spectroscopy for the detection of heavy metals inside it. Atomic absorption spectroscopy (AAS) is an analytical technique that measures the concentration of element. Atomic absorption is so sensitive that it can measure down to parts per billion of a gram $\left(\mu \mathrm{g}^{-3}\right)$ in a sample. The technique makes use of the wavelength of lights specially absorbed by an element. They correspond to the energies to promote electrons from one energy level to another, higher; energy level atomic absorption spectroscopy has many uses in different areas of chemistry.

\section{RESULTS}

\section{Comparative results of lead accumulation in different tissues}

Concentration of lead in gill tissue for tissue for the month of February, March and April was 0.05, 0.04 and 0.03 ppm respectively with Mean $\pm S . D=0.04 \pm 0.01$ as shown in Table 1 and Figure 1.

Similarly concentration of lead in swim bladder tissue for the month of February, March and April was 0.02, 0.02 and 0.01 ppm respectively with Mean $\pm \mathrm{S} . \mathrm{D}=0.01 \pm 0.05$ as shown in Table 1 and Figure 1.

Lead concentration in muscle tissues for the month of February, March and April was 0.03, 0.03 and 0.03 ppm respectively with Mean $\pm \mathrm{S} . \mathrm{D}=0.03 \pm 0$ as shown in Table 1 and Figure 1.

\section{Comparative result of cadmium accumulation in different tissues}

Concentration of cadmium in gills tissue for the month of February, March and April was 0.04, 0.01 ppm and (N.D) respectively with Mean $\pm \mathrm{S} . \mathrm{D}=0.024 \pm 0.01$ as shown in Table 2 and Figure 2.

Similarly concentration of cadmium in swim bladder tissue for the month of February, March and April was (N.D), 0.03 and $0.02 \mathrm{ppm}$ respectively with Mean $\pm \mathrm{S} . \mathrm{D}=0.02 \pm 0.01$ as shown in Table 2 and Figure 2.

Cadmium concentration in muscle tissue for the month of February, March and April was (N.D), 0.01 and (N.D) respectively with Mean $\pm \mathrm{S} . \mathrm{D}=0.01 \pm \mathrm{Nan}$ as shown in Table 2 and Figure 2. 
Table 1: Showing comparative result of lead concentration observed in February, March and April.

\begin{tabular}{|c|c|c|c|c|c|}
\hline S.no & Organs & February & March & April & Mean \pm S.D \\
\hline $\mathbf{1}$ & Gills & $0.05 \mathrm{ppm}$ & $0.04 \mathrm{ppm}$ & $0.03 \mathrm{ppm}$ & $0.04 \pm 0.01$ \\
\hline $\mathbf{2}$ & S.bladder & $0.02 \mathrm{ppm}$ & $0.02 \mathrm{ppm}$ & $0.01 \mathrm{ppm}$ & $0.01 \pm 0.005$ \\
\hline $\mathbf{3}$ & Muscles & $0.03 \mathrm{ppm}$ & $0.03 \mathrm{ppm}$ & $0.03 \mathrm{ppm}$ & $0.03 \pm 0$ \\
\hline
\end{tabular}

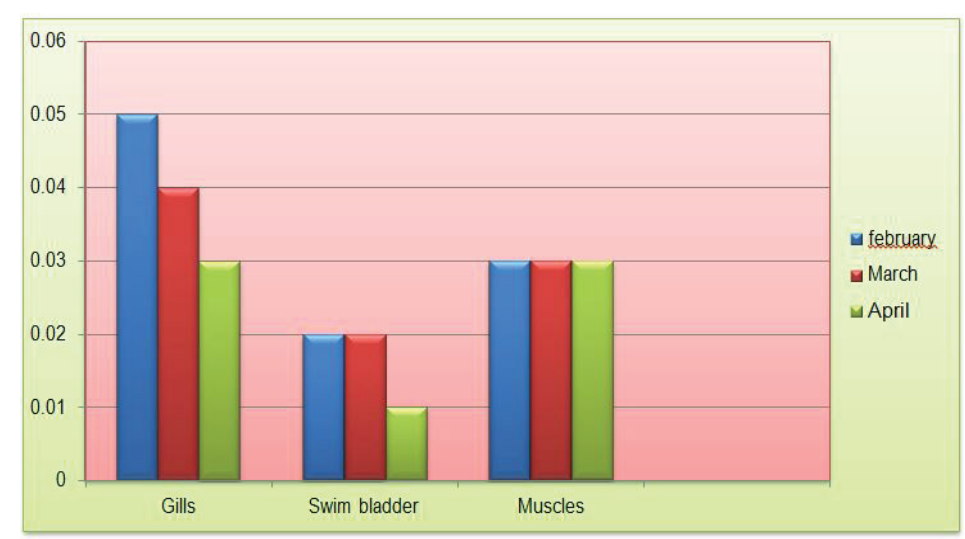

Figure 1: Showing comparative result of lead concentration observed in February, March and April.

Table 2: Showing comparative result of cadmium concentration observed in February, March and April.

\begin{tabular}{|c|c|c|c|c|c|}
\hline S.no & Organs & February & March & April & Mean \pm S.D \\
\hline $\mathbf{1}$ & Gills & $0.04 \mathrm{ppm}$ & $0.01 \mathrm{ppm}$ & N.D & $0.02 \pm 0.02$ \\
\hline $\mathbf{2}$ & S.bladder & N.D & $0.03 \mathrm{ppm}$ & $0.02 \mathrm{ppm}$ & $0.02 \pm 0.01$ \\
\hline $\mathbf{3}$ & Muscles & N.D & $0.01 \mathrm{ppm}$ & N.D & $0.01 \pm$ Nan \\
\hline
\end{tabular}

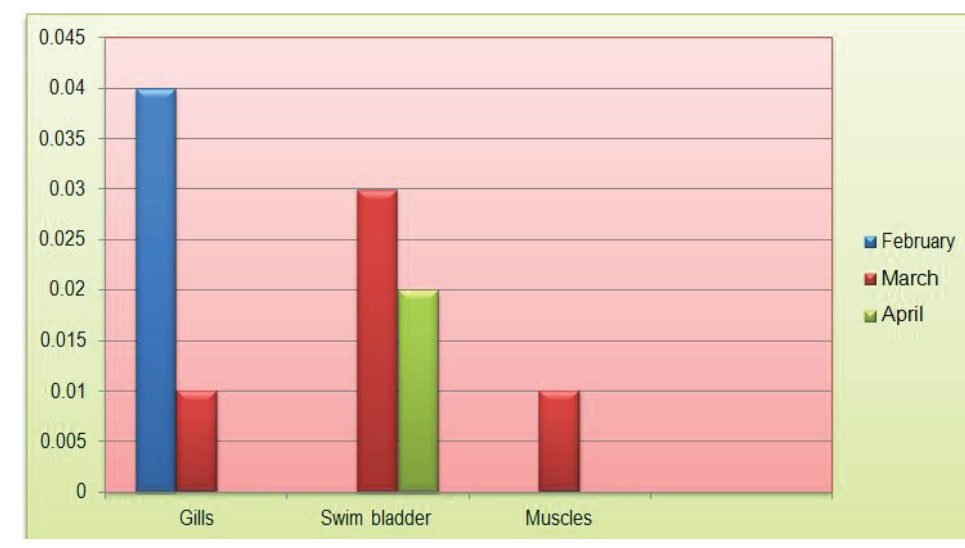

Figure 2: Showing comparative result of lead concentration observed in February, March and April.

\section{DISCUSSION}

Samples were collected from three different sites of river Indus in three different months for the bio accumulation of heavy metals. In the month of February samples were collected from Topi maximum concentration of $\mathrm{Pb}$ was observed in Gills ( $0.05 \mathrm{ppm})$ followed by Muscle tissue $(0.03$ $\mathrm{ppm})$ and Swim bladder tissue is $(0.02 \mathrm{ppm})$. Maximum concentration of $\mathrm{Cd}$ was observed in Gills $(0.004 \mathrm{ppm})$ no Cd was observed in Swim bladder and muscle tissue. Concentration of $\mathrm{Pb}>\mathrm{Cd}$ because untreated water is added from gadoon amazai industries which pollute the Indus river water which is hazardous for fishes and other animals as well as human being. According to Khan et al. found ( $0.05 \mathrm{ppm})$ lead and cadmium in water at Topi near gadoon amazai.
We found that $\mathrm{Pb}$ accumulated in gills. Similar results were obtained by Avenant-Oldewage and Marx, El-Shaikh et al., Kargin, Mendil et al., and Pickering et al. Highest $\mathrm{Pb}$ was recorded in gills because it enters fish body through gills from external aquatic medium (El-Shaikh et al., 2005).

Similarly in the month of March sample was collected from hund. So, maximum accumulation of $\mathrm{Pb}$ was observed in Gills tissue $(0.04 \mathrm{ppm})$ followed by muscle tissue $(0.03 \mathrm{ppm})$ and swim bladder tissue $(0.02 \mathrm{ppm})$ respectively. Fish dwelling in contaminated water with $\mathrm{Pb}$ and $\mathrm{Cr}$ can accumulate higher concentration in gills due to slow excretion rate (AvenantOldewage A et al. 2000, Pickering et al. 1977). Maximum accumulation of $\mathrm{Cd}$ was observed in swim bladder $(0.03$ ppm) followed by Gills and muscle tissue was (0.01 ppm) 
respectively. On the contrary, significant spatial variations of $\mathrm{Cd}$ concentration in fish from streams polluted by cadmium mines in United States were reported (Besser et al., 2007). Highest $\mathrm{Cd}$ and $\mathrm{Cu}$ concentration were recorded in liver as compared to other body organs and tissues. These results are also in accordance with the findings of Avenant Oldewage and Marx., 2000, Kargin 1998, and McCarter and Roch 1983. Cadmium is highly toxic to organisms and can cause anomalies such as reduction in development and growth rates as well as skeletal ossification even at lowest concentration (Wright et al. 2002). In the month of april sample was collected from kund maximum accumulation of lead was observed in gills and muscles tissue $(0.03 \mathrm{ppm})$ followed by swim bladder tissue $(0.01 \mathrm{ppm})$ respectively. Similar findings were reported by (Walsh et al., 2007) that the highest concentrations were in gills, kidney and spleen in rainbow trout. Lead is highly toxics to aquatic organisms, especially fish (Rompala et al., 1984). The biological effects of sublethal concentrations of lead include delayed embryonic development, suppressed reproduction and inhalation of growth, increased mucous formation, neurological problems, enzyme inhalation and kidney disfunction (Rauf et al., 2009). Similarly maximum accumulations of lead were observed in Swim bladder (0.02ppm) and were no $\mathrm{Cd}$ was observed in Muscle and gills tissue. According to Qadir et al. 2011, similar reporting found least amount of Cadmium found in gills and muscle as compared to other tissue of the fish. Qadir et al., 2011 also recorded $\mathrm{Cd}, \mathrm{Cr}$, and $\mathrm{Pb}$ in edible flesh of Labeo rohita collected from Nullah Aik and Nullah Palkhu at $0.8900 \pm 0.06,3.6300 \pm 0.0410$, and $4.3500 \pm 2.0100 \mu \mathrm{g}^{-1}$ respectively, which were much higher levels than those of the present study. In regard to the present study Mastan, 2010 conduct a study to observe heavy metals like cadmium, zinc, copper, chromium, lead and mercury in the various tissues of Labeo rohita and Channa striatus and in the water samples collected from the Kolleru Lake, Andhra Pradesh during 2009-2010. Our present study revealed that maximum accumulation of heavy metals like lead was observed in gills as compared to other tissue and therefore maximum accumulation of Cadmium was observed in Swim bladder as compared to other tissue of fish. Hence Swim bladder and gills tissues showed higher metal concentrations than muscles tissue. Thus, heavy metals when discharged into the Indus River enter the food chain and accumulate in the fish body as determined during this investigation.

\section{REFERENCES}

1. Jabeen, F., Chaudhry, A.S., 2010. Monitoring trace metals in different tissues of Cyprinus carpio from the Indus River in Pakistan. Environ. Monit. Assess., 170: 645-656.

2. Srevastava, S., Goyal, P., 2010. Novel Biomaterial. Environmental science and technology.

3. Ming-Ho, Y. 2005. Environmental Toxicology: Biological and Health Effects of Pollutants, Chap.12, CRC Press LLC, ISBN 1-56670-670-2, 2nd Edition, BocaRaton, USA.
4. Harvey, P. J., Handley, H. K. and Taylor, M. P., 2015. Project $1094-15$ by Tas Water and Water Research Australia.

5. Wright, D.A., Welbourn, P., 2002. Environmental toxicology (Cambridge environmental chemistry series 11). Cambridge University Press., Cambridge.

6. Draghici, C., Coman, G., Jelescu, C., Dima, C. and Chirila, E., 2010. Heavy metals determination in environmental and biological samples, In: Environmental heavy metal pollution and effects on child mental development-risk assessment and prevention strategies. NATO Advanced Research Workshop., Sofia, Bulgaria.

7. Vieira, C., Morais, S., Ramos, S., Delerue-Matos, C. and Oliveira, M. B. P. P., 2011. Mercury, cadmium, lead and arsenic levels in three pelagic fish species from the Atlantic Ocean: Intra- and inter-specific variability and human health risks for consumption. Food. Chem. Toxicol., 49: 923-932.

8. Sesli, E., Tuzen, M., Soylak, M., 2008. Evaluation of trace metal contents of some wild edible mushrooms from Black sea region, Turkey. J. Hazard. Mater., 160: 462-467.

9. Atchison, G. J., Henry, M. G., Sandheinrich, M. B., 1987. Effects of metals on fish behavior: a review. Environ. Biol. Fish., 18: 11-25.

10. Oehlenschläger, J., 2002. Identifying heavy metals in fish In: Safety and Quality issues in fish processing, Bremner, H.A. Wood head Publishing Limited., Cambridge (Edn) Pp: 95-113.

11. Kalay, M., Ay, O., and Canli, M. 1999. Heavy metal concentrations in fish tissues from the Northeast Mediterranean Sea. Bull Environ Contam Toxicol., 63: 673-681.

12. Ademoroti, C. M. A., 1996. Standard method for water and effluents analysis. Foludex Press Ltd., Ibadan.

13. Harrison, N., 2001. Inorganic contaminants in food, In: Food Chemical Safety Contaminants, Watson, D.H. First Edition, Wood head Publishing., Cambridge.

14. Figueroa, E., 2008. Are more restrictive food cadmium standards justifiable health safety measures or opportunistic barriers to trade? An answer from economics and public health. Sci. Total. Environ., 389: 1-9.

15. Mansour, S. A. and Sidky, M. M. 2002. Ecotoxicological Studies: 3. Heavy Metals Contaminating Water and Fish from Fayoum Governorate, Egypt. Food. Chem., 78: 15-22.

16. Castro-González, M. I. and Méndez-Armenta, M., 2008. Heavy metals: Implications associated to fish consumption. Environ. Toxicol. Pharmacol., 26: 263-271.

17. Khan, M. S., Khan, I., Aminurrehman, and Iqbal, Y., 2002. Multielemental study of polluted water of Peshawar valley (N.W.F.P) Pakistan. J. Chem. Soc. $P k ., 24: 3$.

18. Avenant-Oldewage A., Marx, H. M. 2000. Bioaccumulation of chromium, copper and iron in the 
organs and tissues of Clarias gariepinus in the Olifants River, Kruger National Park. Water. Sanit., 26: 569-582.

19. El-Shaikh, K., Nada, A. S., Yousief, Z. A., 2005. Assessment of cadmium and lead in water, sediment and different organs of Procambarus clarkii (Girard, 1852) in the river Nile. Med. J. Isl. Worl. Acad. Sci., 15:161-167.

20. Kargin, F., 1998. Metal concentrations in tissues of the freshwater fish Capoeta barroisi from the Seyhan River (Turkey). Bull. Environ. Contam. Toxicol., 60:822-828.

21. Mendil, M., UluÖzlÜ, Ö. D., Hasdemir. E., TÜzen. M., Sari. H., Suiçmez. M., 2005. Determination of trace metal levels in seven fish species in lakes in Tokat, Turkey. Food. Chem., 90: 175-179.

22. Pickering, Q. H., Brungs, W.A., Gast, M. H., 1977. Effect of exposure time and copper concentration on reproduction of the fathead minnow (Pimepkales promelas). Water. Res., 11: 1079-1983.

23. Sesli, E., Tuzen, M., Soylak, M., 2008. Evaluation of trace metal contents of some wild edible mushrooms from Black sea region, Turkey. J. Hazard. Mater., 160:462-467.

24. Besser, J. M., Brumbaugh, W. G., May, T. W., Schmitt, C. J., 2007. Biomonitoring of lead, zinc and cadmium in streams draining lead-mining and non-mining areas,
Southeast Missouri, USA. Environ. Monit. Assess., 129:227-241.

25. McCarter, J. A., Roch. M., 1983. Hepatic metallothionein and resistance to copper in juvenile coho salmon. Comp. Biochem. Physiol., 74:133-137.

26. Wright, D. A., Welbourn, P., 2002. Environmental toxicology (Cambridge environmental chemistry series 11). Cambridge University Press, Cambridge.

27. Walsh, D. F., Berger, B. L. and Bean, J. R. 1977. Mercury, arsenic, lead, cadmium and selenium residues in fish. 1971-1973. National Pesticide Monitoring Program. Pestic. Monit. J., 11:5-134.

28. Rompala, J. M., Rutosky, F. W and Putnam, D. J. 1984. Concentrations of environmental contaminants from selected waters in Pennsylvania. U.S. Fish. Wildl. Serv. Rep., State College, 21 Pennsylvania, 102.

29. Rauf, A., Javed, M., Ubaidullah, M., 2009. Heavy metal levels in three major carps (Catla catla, Labeo rohita and Cirrhina mrigala) from the river Ravi, Pakistan. Pak. Vet. J., 29: 24-26.

30. Qadir, A., Malik, N. R., 2011. Heavy metals in eight edible fish species from two polluted tributaries (Aik and Palkhu) of the river Chenab, Pakistan. Biol. Trace. Elem. Res., 143:1524-1540. 